IZA DP No. 7669

Immigration and Entrepreneurship

Robert W. Fairlie

Magnus Lofstrom

October 2013

Forschungsinstitut zur Zukunft der Arbeit Institute for the Study of Labor 


\title{
Immigration and Entrepreneurship
}

\author{
Robert W. Fairlie \\ University of California, Santa Cruz \\ and IZA \\ Magnus Lofstrom \\ Public Policy Institute of California \\ and IZA
}

\section{Discussion Paper No. 7669 \\ October 2013}

\author{
IZA \\ P.O. Box 7240 \\ 53072 Bonn \\ Germany \\ Phone: +49-228-3894-0 \\ Fax: +49-228-3894-180 \\ E-mail: iza@iza.org
}

Any opinions expressed here are those of the author(s) and not those of IZA. Research published in this series may include views on policy, but the institute itself takes no institutional policy positions. The IZA research network is committed to the IZA Guiding Principles of Research Integrity.

The Institute for the Study of Labor (IZA) in Bonn is a local and virtual international research center and a place of communication between science, politics and business. IZA is an independent nonprofit organization supported by Deutsche Post Foundation. The center is associated with the University of Bonn and offers a stimulating research environment through its international network, workshops and conferences, data service, project support, research visits and doctoral program. IZA engages in (i) original and internationally competitive research in all fields of labor economics, (ii) development of policy concepts, and (iii) dissemination of research results and concepts to the interested public.

IZA Discussion Papers often represent preliminary work and are circulated to encourage discussion. Citation of such a paper should account for its provisional character. A revised version may be available directly from the author. 
IZA Discussion Paper No. 7669

October 2013

\section{ABSTRACT}

\section{Immigration and Entrepreneurship}

Immigrants are widely perceived as being highly entrepreneurial and important for economic growth and innovation. This is reflected in immigration policies and many developed countries have created special visas and entry requirements in an attempt to attract immigrant entrepreneurs. Not surprisingly, a large body of research on immigrant entrepreneurship has developed over the years. In this chapter we provide an overview of the economics literature with respect to some of the most fundamental immigrant entrepreneurship issues as well as the empirical methods and data used. The main themes we address are immigrant entrepreneurs' contributions to the economy, entrepreneurship differences across groups and group differences in entrepreneurial success.

JEL Classification: J15, J18, J31, J38, J61, L26, M13

Keywords: entrepreneurship, self-employment, innovation, immigrants, immigration

Corresponding author:

Magnus Lofstrom

Public Policy Institute of California (PPIC)

500 Washington Street, Suite 600

San Francisco, CA 94111

USA

E-mail: lofstrom@ppic.org 


\section{Introduction}

Immigrants are widely perceived as being highly entrepreneurial. ${ }^{1}$ Business ownership is higher among the foreign-born than the native-born in many developed countries such as the United States, United Kingdom, Canada and Australia (Borjas 1986; Lofstrom 2002; Clark and Drinkwater 2000, 2010; Schuetze and Antecol 2006; Fairlie et al. 2010). Substantial contributions of immigrant entrepreneurs to the technology and engineering sectors of the economy, especially in Silicon Valley, have also been well documented and have received broad attention (Wadwha, et al. 2007; Saxenian 1999, 2000). In an attempt to attract immigrant entrepreneurs, many developed countries have created special visas and entry requirements for immigrant entrepreneurs (Schuetze and Antecol 2006). In the United States, for example, special preferences for admission are given to immigrants who invest $\$ 1$ million in businesses and create or preserve at least 10 full-time jobs for U.S. workers, and recently, the Startup Act 2.0 bill proposes to expand opportunities for immigrants to start businesses in the United States (U.S. Department of Homeland Security 2012).

Immigrant entrepreneurship is becoming increasingly important in the U.S. as both immigration and foreign-born business ownership has grown steadily over the last decades. Approximately 16 percent of the U.S. workforce was foreign born in 2009, a proportion that has more than doubled since its 7 percent share in 1980 (Lofstrom, 2009). Over the same time period, self-employment grew strongly and immigrants continued to increase their share of business owners. Figure 1 shows an increase of close to 7 million business owners from 1980 to 2010 and that immigrants’ share of self-employment increased from about 6.9 percent to 18.4 percent. Although not entirely clear from the

\footnotetext{
${ }^{1}$ We use the terms self-employed, entrepreneur and business owner synonymously in this chapter.
} 
figure, the increase in the foreign born self-employment share in the last decade is partially driven by the slowdown in native self-employment growth, which started around the beginning of the Great Recession in 2007. 
Figure 1

Self-Employment Levels by Nativity and Foreign Born Self-Employment Share , 19802010.

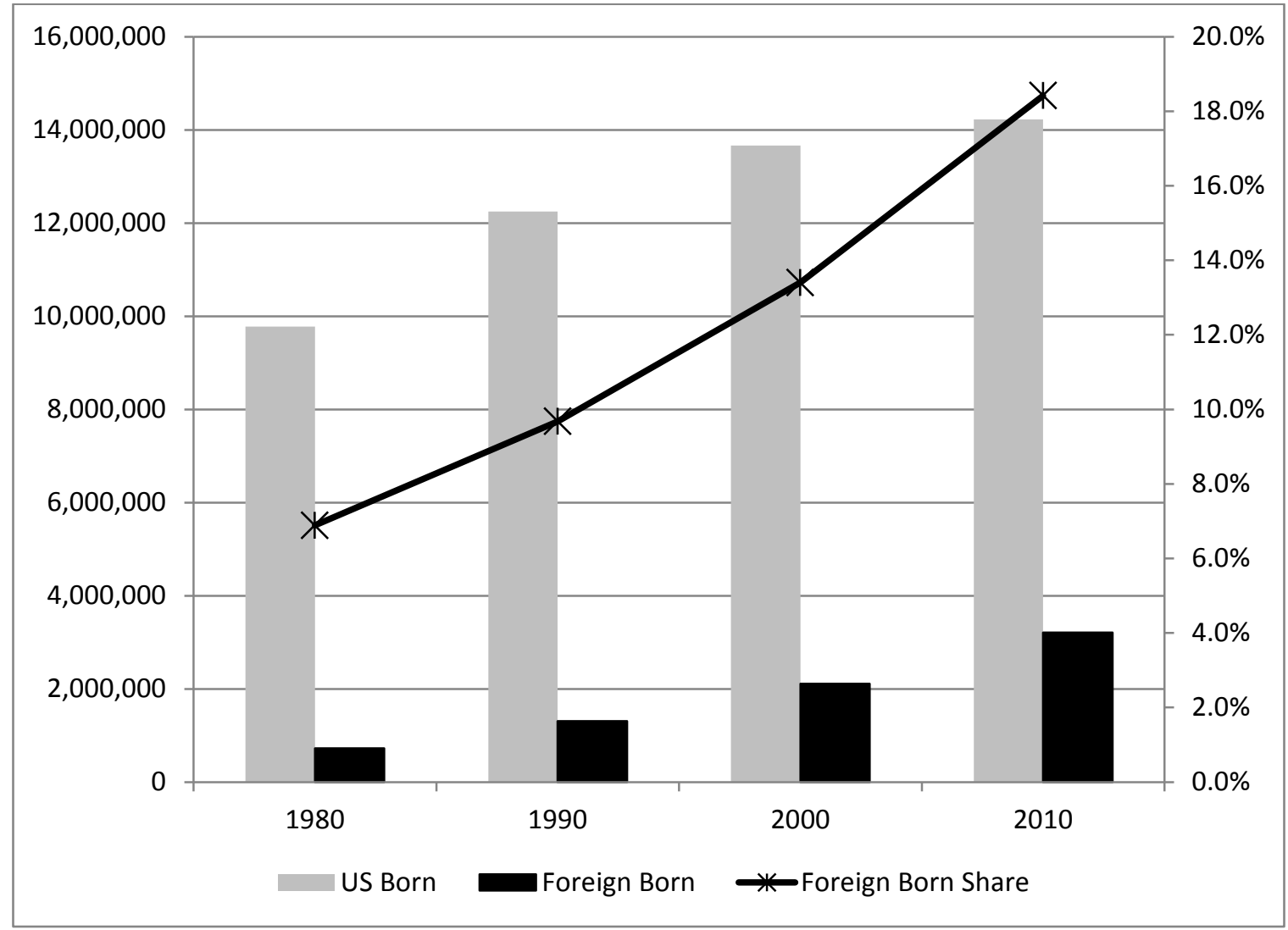

Source: 1980, 1990 and 2000 U.S. Census and 2010 American Community Survey.

A growing body of research on immigrant entrepreneurship has developed over

the past several years. In this chapter we provide an overview of the economics literature with respect to some of the most fundamental immigrant entrepreneurship issues as well as the empirical methods and data used. We review this literature through the lens of estimating the net contribution made by immigrant entrepreneurs to the host economy. Immigration is a very hotly debated topic because of the contrasting concerns over lowering wages for existing workers, increasingly public assistance rolls, security and changing the demographic makeup of host countries, and the need for less- and highskilled workers, supporting an aging population, insourcing instead of outsourcing labor, 
and family reunification. Central to the debate is whether immigrants provide a net positive or net negative contribution to host economy. Partly fueled by this debate, an extremely large literature in economics examines the separate impacts of immigrants on various parts of the economy such as the labor market, public assistance, tax system, and educational systems. ${ }^{2}$ Since much of the attention of the relevant research has been on the United States, this will be the focus of our discussion.

Evaluating the ways in which immigrant entrepreneurs contribute to the economy provides a useful and novel framework for reviewing the previous literature.

Fundamental to evaluating how immigrants contribute to entrepreneurship and small business ownership is examining patterns of business ownership. Several previous studies examine immigrant business ownership focusing on explaining group differences especially using decomposition techniques. The performance of immigrant-owned businesses is also fundamental to understanding their contribution to the host economy. Previous research examines assimilation and its effects on immigrant self-employment earnings, and also examines immigrant group differences in business earnings. A third area is whether immigrant entrepreneurs displace native entrepreneurs, have positive spillovers in technology and innovation, and contribute to diversity in products and services in the host country. A small, but new and emerging literature tackles these difficult questions. Finally, the ability of immigrant-owned businesses to export back to their home countries, and thus potentially expand the host country's economy represents another important and understudied topic.

\footnotetext{
${ }^{2}$ See Borjas (1994) and Kerr and Kerr (2011) for reviews of this literature. To our knowledge, the literature focusing on immigrant entrepreneurship has not been previously reviewed in the economics literature.
} 
In addition to being a relatively understudied aspect of overall impacts of immigration on host economies, the focus of this chapter on contributions to entrepreneurship and small business ownership is important economically. Promoting entrepreneurship is viewed as a national priority by governments around the world. The interest is driven primarily by evidence that small businesses create a disproportionate share of new jobs in the economy, represent an important source of innovation, increase national productivity and alleviate poverty (see Reynolds 2005; OECD 2006; U.S. Small Business Administration 2011 for example). ${ }^{3}$ The self-employed are also unique in that they create jobs for themselves, representing more than ten percent of total employment in the United States and many other countries.

The rest of the chapter proceeds as follows. Section 2 documents the large contributions immigrant entrepreneurs make to the U.S. economy. Section 3 examines differences in business ownership rates across immigrant groups by first examining who is an immigrant entrepreneur. We then briefly discuss some of the methodology commonly used in the literature to study the causes of these differences, and end the section by providing a detailed review of the literature explaining group differences. Section 4 reviews the literature on immigrant business performance. Section 5 discusses additional areas of importance, such as crowd out, spillovers and diversity, for evaluating the overall contribution of immigrant entrepreneurs. Section 6 concludes and discusses future areas of research.

\footnotetext{
${ }^{3}$ Haltiwanger, Jarmin and Miranda (2011) refine the argument that small businesses create a disproportionate number of jobs by showing that business startups and young businesses are the ones contributing substantially to both gross and net job creation.
} 


\section{The Contribution of Immigrant Entrepreneurs to the Economy}

Immigrants make substantial contributions to business ownership, business income and employment in the United States. In this section, we present some estimates from the American Community Survey documenting just how large these contributions are to the U.S. economy. Estimates from the 2006-10 ACS indicate that there are 2.4 million immigrant business owners, representing 18.2 percent of all business owners (the ACS data are discussed in detail in Appendix A). The large immigrant share of all business owners compares favorably to the immigrant share of the work force. Immigrants constitute 16.3 percent of the total U.S. work force, implying a higher business ownership rate than the U.S.-born rate. Indeed, 11.0 percent of immigrants own a business, compared with 9.6 percent of the U.S.-born work force. This finding is consistent with several previous studies that document higher business ownership rates among immigrants. We review this literature below in Section 3.

We next examine the question of what is the immigrant contribution to business startup activity in the United States. A separate analysis of business startup activity is important because new businesses are often associated with economic growth, innovation, and the creation of jobs. To measure business startup activity, we use panel data created by matching consecutive months of the 2007-2011 Current Population Survey (CPS). Immigrants represent 24.9 percent of all new business owners in the United States. The share of business startup activity generated by immigrants is much higher than the immigrant share of the workforce at risk of starting a business each month. We find that immigrants represent 15.6 percent of the non-business owning workforce. The higher share of immigrant business startup activity translates into much 
higher rates of business formation by immigrants than nonimmigrants. The business formation rate per month among immigrants is 0.51 percent; that is, of 100,000 nonbusiness-owning immigrants, 510 start a business each month. This rate of business formation is higher than the nonimmigrant rate of 0.28 percent, or 280 of 100,000 U.S.born non-business owners per month.

We also explore the question of how much immigrant-owned businesses contribute to total business income in the United States. The answer to this question tells us something about how much value immigrant entrepreneurs create for the U.S. economy? We address this question using two measures based on available data. First, we examine the contribution of immigrant business owners to total business income generated by all U.S. business owners using ACS data. The second and related measure that we examine is total sales and receipts by immigrant-owned businesses using data from specially commissioned tabulations from the 2007 Survey of Business Owners.

The total business income for immigrants is $\$ 121$ billion, representing 15.0 percent of all business income in the United States. Total U.S. business income is $\$ 808$ billion. The immigrant representation of total business income is lower than the representation of the total number of business owners, suggesting that immigrant-owned businesses have lower average incomes. Immigrant-owned business income is $\$ 49,779$ on average, compared with $\$ 62,695$ for nonimmigrants. We discuss the literature that examines average business earnings among immigrants and how this is related to assimilation in the home country below in Section 4.

The immigrant-owned business contribution to total sales and receipts is examined next. Estimates from the SBO indicate that immigrant-owned business 
generated 10.0 percent of total sales generated by firms in which the majority foreign born status can be classified (Table 1). Firms that are equally foreign- and native-born owned represent 1.8 percent of firms and 1.3 percent of total sales. Adding these firms to those with 51 percent foreign-born ownership, results in a total share of firms with 50 percent or more foreign-born ownership of 15.0 percent.

Table 1

Total Sales for Immigrant and Non-Immigrant Owned Firms Special Tabulations from Survey of Business Owners (2007)

\begin{tabular}{lcrrr} 
& $\begin{array}{c}\text { Number of } \\
\text { Ownership }\end{array}$ & $\begin{array}{c}\text { Share of } \\
\text { Total Firms }\end{array}$ & \multicolumn{1}{c}{$\begin{array}{c}\text { Total Sales } \\
(\$ 000 s)\end{array}$} & \multicolumn{1}{c}{$\begin{array}{c}\text { Share of } \\
\text { Total Sales }\end{array}$} \\
\hline Immigrant (majority foreign-born) & $1,798,541$ & $13.4 \%$ & $\$ 779,833,278$ & $10.0 \%$ \\
Non-immigrant (majority native-born) & $11,578,280$ & $86.6 \%$ & $\$ 7,047,737,009$ & $90.0 \%$ \\
Total immigrant and non-immigrant & $13,376,821$ & $100.0 \%$ & $\$ 7,827,570,287$ & $100.0 \%$ \\
Equally foreign-/native-born & 244,070 & & $\$ 102,760,238$ & \\
Foreign-born status indeterminate & $12,673,969$ & & $\$ 3,019,131,351$ & \\
\hline
\end{tabular}

Note: (1) The sample includes businesses that are classified by the IRS as sole proprietorships, partnerships, 1120 corporations, or employers, and that have sales of $\$ 1000$ or more. (2) Excludes publicly held and other firms not classifiable by owner status.

On average, immigrant firms have lower sales than non-immigrant firms. Immigrant-owned firms have $\$ 434,000$ in average annual sales and receipts compared with \$609,000 among non-immigrant firms. ${ }^{4}$ These patterns reflect those found for average levels of business income. On average, immigrant-owned businesses produce lower earnings. But, as noted below this comparison hides important differences by time in the country and source country.

Using data from the SBO, we next examine how immigrant-owned businesses contribute to total employment. Immigrant-owned businesses are found to make large contributions to total employment in the United States. Table 2 reports estimates of the

\footnotetext{
${ }^{4}$ Firms that are equally foreign and U.S.-born owned have a similar level of average sales as firms that are majority foreign owned $(\$ 421,000)$. Firms with an indeterminate foreign owned status have lower average sales at $\$ 238,000$.
} 
share of employer firms owned by immigrants and total employment by immigrantowned businesses. Immigrants own 14.1 percent of businesses hiring employees. This share is roughly similar to share for the number of businesses presented in Table 1 indicating that immigrant-owned businesses are similarly likely to hire any employees than are non-immigrant owned businesses.

Table 2

Employment for Immigrant and Non-Immigrant Owned Firms Special Tabulations from Survey of Business Owners (2007)

\begin{tabular}{lrrrr} 
Ownership & $\begin{array}{c}\text { Number of } \\
\text { Employer Firms }\end{array}$ & $\begin{array}{c}\text { Share of Total } \\
\text { Empl. Firms }\end{array}$ & $\begin{array}{c}\text { Total } \\
\text { Employment }\end{array}$ & $\begin{array}{r}\text { Share of Total } \\
\text { Employment }\end{array}$ \\
\hline Immigrant (majority foreign-born) & 501,973 & $14.1 \%$ & $3,997,977$ & $9.9 \%$ \\
Non-immigrant (majority native-born) & $3,049,698$ & $85.9 \%$ & $36,426,585$ & $90.1 \%$ \\
Total immigrant and non-immigrant & $3,551,671$ & $100.0 \%$ & $40,424,562$ & $100.0 \%$ \\
Equally foreign-/native-born & 74,006 & & 642,138 & \\
Foreign-born status indeterminate & $1,564,291$ & & $15,559,855$ & \\
\hline
\end{tabular}

Note: (1) The sample includes businesses that are classified by the IRS as sole proprietorships, partnerships, 1120 corporations, or employers, and that have sales of $\$ 1000$ or more. (2) Excludes publicly held and other firms not classifiable by owner status.

Immigrant businesses also hire roughly 10 percent of employees hired by identifiable firms in the United States. Among firms hiring employees, immigrant-owned businesses hire an average of 8 employees each.

Table 3 reports the share of total payroll by immigrant-owned businesses. The immigrant share of total payroll is 8.8 percent. The average immigrant-owned employer business in the United States pays out $\$ 252,758$ to its employees. The average paid to each of those employees is $\$ 31,740$. These average annual wages and salaries paid to employees are not substantially lower than the amount paid by non-immigrant firms of \$35,880 per employee. 
Table 3

Payroll for Immigrant and Non-Immigrant Owned Firms

Special Tabulations from Survey of Business Owners (2007)

\begin{tabular}{|c|c|c|c|c|}
\hline Ownership & $\begin{array}{c}\text { Number of } \\
\text { Employer Firms }\end{array}$ & $\begin{array}{c}\text { Share of Total } \\
\text { Empl. Firms }\end{array}$ & $\begin{array}{c}\text { Total Payroll } \\
(\$ 000 \mathrm{~s})\end{array}$ & $\begin{array}{c}\text { Share of Total } \\
\text { Payroll }\end{array}$ \\
\hline Immigrant (majority foreign-born) & 501,973 & $14.1 \%$ & $\$ 126,877,578$ & $8.8 \%$ \\
\hline Non-immigrant (majority native-born) & $3,049,698$ & $85.9 \%$ & $\$ 1,306,936,752$ & $91.2 \%$ \\
\hline Total immigrant and non-immigrant & $3,551,671$ & $100.0 \%$ & $\$ 1,433,814,330$ & $100.0 \%$ \\
\hline Equally foreign-/native-born & 74,006 & & $\$ 21,106,032$ & \\
\hline Foreign-born status indeterminate & $1,564,291$ & & $\$ 485,652,582$ & \\
\hline
\end{tabular}

Note: (1) The sample includes businesses that are classified by the IRS as sole proprietorships, partnerships, 1120 corporations, or employers, and that have sales of $\$ 1000$ or more. (2) Excludes publicly held and other firms not classifiable by owner status.

Immigrant business owners constitute a large share of all business owners in the United States, but their contributions might be even larger to specific sectors of the U.S. economy. Previous research finds evidence of differential contributions by immigrants. For example, Wadwha et al. (2007) find that 25 percent of engineering and technology companies started in the past decade were founded by immigrants and Saxenian (1999, 2002) finds evidence that immigrant entrepreneurs play an important role in the success and development of California’s Silicon Valley. We briefly examine whether immigrant business owners contribute differently to high-skilled businesses, industries, and states. Focusing on education (or skills) first, we find that nearly 45 percent of all business owners with less than a high school degree are immigrants. Immigrant business owners with a college degree also represent a large share of all business owners with a college degree (15.7 percent).

Immigrant business owners make notable contributions to the U.S. economy in several industries. More than one-quarter of all businesses in the transportation, accommodation, recreation and entertainment, and other services industries are owned by immigrants. Immigrant-owned businesses also contribute substantially to retail trade 
(22.6 percent), wholesale trade (20.3 percent), and health care and social assistance (20.0 percent).

Immigrant business owners are heavily concentrated in California, New York, Florida, and Texas and may contribute more to the economies of these states than others. Immigrant business owners represent a very large share of all business owners in the California. Nearly 37 percent of all business owners in California are immigrants. Roughly 30 percent of all business owners in New York, Florida and New Jersey are foreign-born, and roughly one-fourth of all business owners in Texas and Hawaii are foreign-born. Immigrant contributions to business ownership in all these states are substantially higher than the national average of 18.2 percent.

Estimates from the ACS clearly indicate that immigrants make significant contributions to business ownership, formation, and income in the United States. The economic contributions of immigrant business owners are also unevenly distributed across the United States, with the largest contributions located in California and other "gateway" states, and are more concentrated in specific sectors of the economy. The large contributions made by immigrant entrepreneurs, especially in specific locations and sectors, are partly responsible for the considerable research interest generated on the subject, which we review in the next section.

\section{Immigrant Business Ownership}

Previous research documents that business ownership is higher among the foreign-born than the native-born in many developed countries such as the United States, United Kingdom, Canada and Australia (Borjas 1986; Lofstrom 2002; Clark and 
Drinkwater 2000, 2006; Schuetze and Antecol 2006; Fairlie et al. 2010). As noted above, the business ownership rate among immigrants is 11.0 percent in the United States, which is 15 percent higher than the native born rate of 9.6 percent. Business creation rates are also substantially higher among immigrants than natives.

Several previous studies have examined explanations for high rates of business ownership and creation among immigrants. Several of these studies have also examined the causes of substantial heterogeneity in rates across immigrant groups. This research has predominately relied on decomposition techniques. Before reviewing this literature, however, we return to the ACS data to explore the characteristics of immigrant entrepreneurs and their businesses.

\section{Who are Immigrant Entrepreneurs in the United States?}

Where do immigrant business owners come from? Table 4 reports estimates of the number and share of business owners by source country for the top 20 countries. The largest contributing country is Mexico, with 570,170 business owners representing nearly a quarter of all immigrant business owners in the United States. Korean immigrant business owners make up the next largest share of business owners, with 5.1 percent. Indian and Vietnamese immigrants also represent relatively large shares of immigrant business owners (more than 4 percent for each group). Another clear pattern revealed from the table, however, is the diversity of source countries of immigrants residing in the United States. The 20 countries combined still represent less than three quarters of all immigrant business owners. The only clear outlier for representation of among different immigrant groups is those from Mexico. 
Table 4

Number and Share of Business Owners by Source Country

American Community Survey 2006-10

\begin{tabular}{lrrr}
\multicolumn{5}{c}{ Business Owners } \\
Group & \multicolumn{1}{c}{$\begin{array}{c}\text { Percent of } \\
\text { Immigrant Total }\end{array}$} & $\begin{array}{c}\text { Business } \\
\text { Ownership Rate }\end{array}$ \\
\hline U.S. Total & $13,385,470$ & & $9.8 \%$ \\
U.S. Born Total & $10,950,850$ & & $9.6 \%$ \\
Immigrant Total & $2,434,620$ & $100.0 \%$ & $11.0 \%$ \\
Mexico & 570,170 & $23.4 \%$ & $8.4 \%$ \\
Korea & 123,770 & $5.1 \%$ & $23.1 \%$ \\
India & 99,830 & $4.1 \%$ & $9.5 \%$ \\
Vietnam & 98,950 & $4.1 \%$ & $14.0 \%$ \\
China & 75,530 & $3.1 \%$ & $10.0 \%$ \\
Cuba & 75,050 & $3.1 \%$ & $14.8 \%$ \\
El Salvador & 73,540 & $3.0 \%$ & $9.6 \%$ \\
Canada & 57,650 & $2.4 \%$ & $14.2 \%$ \\
Philippines & 55,450 & $2.3 \%$ & $5.1 \%$ \\
Guatemala & 52,840 & $2.2 \%$ & $10.6 \%$ \\
Colombia & 49,670 & $2.0 \%$ & $13.1 \%$ \\
Brazil & 47,060 & $1.9 \%$ & $21.0 \%$ \\
Iran & 45,330 & $1.9 \%$ & $24.4 \%$ \\
Dominican Republic & 41,110 & $1.7 \%$ & $9.2 \%$ \\
Poland & 40,870 & $1.7 \%$ & $15.6 \%$ \\
Germany & 35,540 & $1.5 \%$ & $13.3 \%$ \\
Honduras & 32,950 & $1.4 \%$ & $11.2 \%$ \\
Jamaica & 31,890 & $1.3 \%$ & $7.8 \%$ \\
Peru & 31,320 & $1.3 \%$ & $12.1 \%$ \\
Italy & 30,750 & $1.3 \%$ & $20.1 \%$ \\
\hline
\end{tabular}

Notes: 1) The sample includes all workers with 15 or more hours worked per usual week The total sample size is $6,644,017$. 2) All reported estimates use sample weights provided by the ACS. 3) The reported immigrant groups represent the largest 20 groups based on the number of business owners.

Table 4 also reports business ownership rates by source country. Of these groups, Mexican immigrants have a rate of business ownership below the national average (8.4 percent compared with 9.8 percent). The large contribution to the total number of immigrant business owners is thus being driven by the large share of Mexican immigrants in the United States and not by higher business ownership rates. In contrast, 23.1 percent of Korean immigrants own a business, one reason they represent the second largest number of immigrant business owners in the United States. 
Table 5 reports estimates of the number and share of immigrant business owners by education level. The largest educational group among immigrants is college graduates. Nearly 30 percent of all immigrant business owners have a college degree. The next largest category is having less than a high school degree. Roughly one-quarter of immigrant business owners have less than a high school degree.

Table 5

Number and Share of Immigrant Business Owners by Education Level American Community Survey 2006-10

\begin{tabular}{lrc} 
Education Level & Number & $\begin{array}{c}\text { Percent of } \\
\text { Immigrant Total }\end{array}$ \\
\hline All education levels & $2,434,610$ & $100.0 \%$ \\
Less than high school & 625,680 & $25.7 \%$ \\
High school graduate & 592,880 & $24.4 \%$ \\
Some college & 490,510 & $20.1 \%$ \\
College graduate & 725,540 & $29.8 \%$ \\
\hline
\end{tabular}

Notes: 1) The sample includes all business owners with 15 or more hours worked per usual week. 2) All reported estimates use sample weights provided by the ACS.

Immigrants are heavily concentrated in California, New York, Florida, and Texas (U.S. Department of Homeland Security, 2011). The geographical concentration of immigrant business owners reflects these general patterns. Table 6 reports estimates of the number and share of immigrant business owners by state. California has by far the largest number of immigrant business owners, with 676,537. These immigrant business owners represent 27.8 percent of all immigrant business owners in the United States. Immigrant business owners in Florida, New York, and Texas also have large concentrations of immigrant business owners. In contrast to the disperse distribution of immigrant business owners across source countries, immigrant business owners are much more geographically concentrated. 
Table 6

Number of Immigrant Business Owners by State American Community Survey 2006-10

\begin{tabular}{|c|c|c|}
\hline Industry & Number & $\begin{array}{c}\text { Percent of } \\
\text { Immigrant Total }\end{array}$ \\
\hline U.S. Total & $2,434,621$ & $100.0 \%$ \\
\hline Alabama & 7,968 & $0.3 \%$ \\
\hline Alaska & 3,394 & $0.1 \%$ \\
\hline Arizona & 50,706 & $2.1 \%$ \\
\hline Arkansas & 6,171 & $0.3 \%$ \\
\hline California & 676,537 & $27.8 \%$ \\
\hline Colorado & 27,645 & $1.1 \%$ \\
\hline Connecticut & 31,320 & $1.3 \%$ \\
\hline Delaware & 3,320 & $0.1 \%$ \\
\hline District of Columbia & 4,003 & $0.2 \%$ \\
\hline Florida & 286,144 & $11.8 \%$ \\
\hline Georgia & 63,342 & $2.6 \%$ \\
\hline Hawaii & 15,997 & $0.7 \%$ \\
\hline Idaho & 4,051 & $0.2 \%$ \\
\hline Illinois & 99,810 & $4.1 \%$ \\
\hline Indiana & 11,995 & $0.5 \%$ \\
\hline lowa & 4,823 & $0.2 \%$ \\
\hline Kansas & 7,378 & $0.3 \%$ \\
\hline Kentucky & 6,143 & $0.3 \%$ \\
\hline Louisiana & 14,726 & $0.6 \%$ \\
\hline Maine & 2,711 & $0.1 \%$ \\
\hline Maryland & 50,028 & $2.1 \%$ \\
\hline Massachusetts & 50,778 & $2.1 \%$ \\
\hline Michigan & 30,223 & $1.2 \%$ \\
\hline Minnesota & 15,001 & $0.6 \%$ \\
\hline Mississippi & 4,534 & $0.2 \%$ \\
\hline Missouri & 11,414 & $0.5 \%$ \\
\hline Montana & 1,061 & $0.0 \%$ \\
\hline Nebraska & 3,905 & $0.2 \%$ \\
\hline Nevada & 20,000 & $0.8 \%$ \\
\hline New Hampshire & 4,253 & $0.2 \%$ \\
\hline New Jersey & 101,251 & $4.2 \%$ \\
\hline New Mexico & 11,440 & $0.5 \%$ \\
\hline New York & 261,140 & $10.7 \%$ \\
\hline North Carolina & 33,120 & $1.4 \%$ \\
\hline North Dakota & 381 & $0.0 \%$ \\
\hline Ohio & 20,768 & $0.9 \%$ \\
\hline Oklahoma & 11,983 & $0.5 \%$ \\
\hline Oregon & 22,216 & $0.9 \%$ \\
\hline Pennsylvania & 38,799 & $1.6 \%$ \\
\hline Rhode Island & 6,478 & $0.3 \%$ \\
\hline South Carolina & 11,869 & $0.5 \%$ \\
\hline South Dakota & 606 & $0.0 \%$ \\
\hline Tennessee & 15,369 & $0.6 \%$ \\
\hline Texas & 256,849 & $10.5 \%$ \\
\hline Utah & 9,229 & $0.4 \%$ \\
\hline Vermont & 1,700 & $0.1 \%$ \\
\hline Virginia & 53,709 & $2.2 \%$ \\
\hline Washington & 45,696 & $1.9 \%$ \\
\hline West Virginia & 1,486 & $0.1 \%$ \\
\hline Wisconsin & 10,342 & $0.4 \%$ \\
\hline Wyoming & 809 & $0.0 \%$ \\
\hline
\end{tabular}

Notes: 1) The sample includes all business owners with 15 or more hours worked per usual week. 2) All reported estimates use sample weights provided by the ACS. 
What are the characteristics of the businesses owned by immigrant entrepreneurs?

We first examine the industry distribution of immigrant-owned businesses in the United States. Table 7 reports estimates of the number of immigrant business owners by major industry group. Immigrant business owners have large concentrations in Construction, Professional Services, and Other Services, with each industry capturing more than 15 percent of the total. Roughly 10 percent of immigrant business owners are also represented in Retail Trade, Health Care and Social Assistance, and Accommodation, Recreation and Entertainment.

Table 7

Number and Share of Immigrant Business Owners by Industry American Community Survey 2006-10

\begin{tabular}{lrc} 
& & Percent of \\
Industry & Number & Immigrant Total \\
\hline All Industries & $2,434,607$ & $100.0 \%$ \\
Agriculture & 26,750 & $1.1 \%$ \\
Extraction & 1,290 & $0.1 \%$ \\
Construction & 417,540 & $17.2 \%$ \\
Manufacturing & 78,640 & $3.2 \%$ \\
Wholesale trade & 79,560 & $3.3 \%$ \\
Retail trade & 263,250 & $10.8 \%$ \\
Transportation & 143,110 & $5.9 \%$ \\
Information & 19,880 & $0.8 \%$ \\
Finance & 133,500 & $5.5 \%$ \\
Professional Services & 406,970 & $16.7 \%$ \\
Educational Services & 24,850 & $1.0 \%$ \\
Health Care and Social Assistance & 237,580 & $9.8 \%$ \\
Accommodation, Recreation and Entertainment & 207,670 & $8.5 \%$ \\
Other services & 394,017 & $16.2 \%$ \\
\hline
\end{tabular}

Notes: 1) The sample includes all business owners with 15 or more hours worked per usual week. 2) All reported estimates use sample weights provided by the ACS.

Another measure of interest is the share of immigrant business owners that own incorporated vs. unincorporated businesses in the United States. Incorporated businesses are generally more successful than unincorporated businesses. Incorporating a small business provides limited liability for the owner, but can also be costly and subjects the 
business to additional legal and financial restrictions. Estimates from the ACS indicate that 34.9 percent of all immigrant business owners own incorporated businesses, which is roughly similar to the percentage for non-immigrant owned businesses. Immigrant business owners do not appear to be overly clustered in less profitable and less regulated unincorporated businesses.

\section{Methodology for Analyzing Immigrant Group Differences in Entrepreneurship}

Most of the existing research on immigrant entrepreneurship aims to explain differences in business ownership rates between immigrants and natives and/or differences across immigrant groups. A common starting point for this strand of work is typically to model the self-employment decision, which can be entry or exit, as one to maximize expected utility subject to the constraints faced by the individual. As such, the framework can shed light on factors making self-employment more (less) rewarding for a particular group as well as easier (harder) to attain than it is for a comparison group. Appendix B provides further details on how the utility model is used to represent the selfemployment decision.

To assess the role of the observable characteristics in explaining the ethnic/racial self-employment gap the self-employment models are typically estimated as probit or logit models. Coefficient estimates and standard errors from these regressions are used to identify the determinants of self-employment and whether immigrant differences remain after controlling for these determinants, which often include individual, family, source country, and geographical characteristics. The estimates and the values of the observed characteristics can also be utilized in a nonlinear Blinder-Oaxaca decomposition (Fairlie 
1999, 2003) to determine their contributions of each type of characteristic on the observed differences in self-employment. The decomposition technique is described in detail in Appendix C. The technique can provide an answer, for example, to the question of how much of the difference in business ownership rates between two immigrant groups is due to one group having a higher education level than the other group, or whether the difference in business ownership rates between immigrants and natives can be explained by differences in education.

\section{Explaining Group Differences - Literature Review}

Existing research has analyzed numerous factors and their roles in explaining group differences in self-employment. These include human capital, wealth and access to financial capital, parental entrepreneurship, home country business experience, ethnic enclaves, blocked opportunities in formal employment as well as selection. This is a large body of literature with numerous contributions from both sociologists and economists. Here we predominantly review the work of economists.

\section{Human Capital}

Human capital, measured by education and language proficiency, plays a prominent role and has been found in the literature to be a major determinant of business ownership differences across groups. Although it is widely accepted that education plays an important part in the success or failure of small businesses, its role in explaining entry into firm ownership is unclear since higher education increases individuals’ opportunities and compensation in wage/salary work. As such, it increases the opportunity costs of entrepreneurship and, all else equal, makes entry into self-employment less likely. 
However, education is also likely to generate skills that are associated with greater success, such as analytical abilities, communication skills, and other skills needed to run a business successfully. Although much of the research points towards a positive relationship between education and business ownership, the evidence is somewhat mixed (van der Sluis et al, 2008). Lofstrom, Bates and Parker (forthcoming) postulates that this may be due to sorting into industries based on entry barriers. They find that educational credentials of highly educated potential entrepreneurs, in particular, is associated with lower probability of small-firm ownership in some less financially rewarding industries while it encourages entry into higher barrier industries that also offer higher returns.

The literature focusing on the role of human capital in explaining group differences in business ownership provides a much less ambiguous picture, especially in studies of the low self-employment rates of the immigrant fueled largest and fastest growing ethnic minority group in the U.S., Latinos. At the other end of the spectrum is another quickly growing group, again primarily due to immigration but with much different experiences in the U.S., Asians.

Low levels of education obtained by Latinos are partly responsible for their lower business ownership rates. Estimates from non-linear decompositions using the CPS indicate that education differences account for 32.8 to 37.9 percent of the entry rate gap for Mexican-Americans (Fairlie and Woodruff 2007). Lofstrom and Wang (2009) find that education is important in explaining differences is business creation rates between Mexican-Americans and whites, as well as the types of businesses entrepreneurs are likely to pursue. The high rate of business ownership by Asians is in part due to their relatively high levels of education (Fairlie 2006). 
Another measure of human capital relevant for Latinos and Asians is language ability. Limited English language ability may make it difficult to communicate with potential customers and suppliers, and learn about regulations. On the other hand, lack of fluency in English may limit opportunities in the wage/salary sector resulting in an increased likelihood of becoming self-employed. Previous studies provide some evidence that a better command of the English language is associated with more selfemployment (see Fairlie and Meyer 1996 and Fairlie and Woodruff 2010 for example). But, there is also a literature that points to blocked opportunities in the wage/salary sector because of language barriers increasing self-employment among Asian immigrants (Kassoudji 1988, Min 1989, 1993, Bates 1997).

\section{Wealth and Access to Financial Capital}

One of the most important barriers preventing would-be entrepreneurs from starting businesses and small businesses from growing is inadequate access to financial capital. The importance of personal wealth as a determinant of entrepreneurship has been the focus of an extensive body of literature. Numerous studies using various methodologies, measures of wealth and country microdata explore the relationship between wealth and entrepreneurship. Most studies find that asset levels (e.g. net worth) measured in one year increase the probability of starting a business by the following year. ${ }^{5}$ The finding has generally been interpreted as providing evidence that entrepreneurs face liquidity constraints, but there is some debate over the evidence (e.g.

\footnotetext{
${ }^{5}$ For a few examples, see Evans and Jovanovic (1989), Evans and Leighton (1989), Holtz-Eakin, Joulfaian, and Rosen (1994), Lindh and Ohlsson (1996), Black, de Meza and Jeffreys (1996), Blanchflower and Oswald (1998), Dunn and Holtz-Eakin (2000), Taylor (2001), Zissimopoulos, Karoly, and Gu (2009), and Fairlie and Krashinsky (2012).
} 
see Hurst and Lusardi 2004 and Fairlie and Krashinsky 2012). Personal wealth can be invested directly in the business, used as collateral to obtain business loans, or used through home equity lines. ${ }^{6}$

Previous studies have documented that Latinos have substantially lower levels of wealth than whites (see Wolff 2000 and Cobb-Clark and Hildebrand 2004). The latest estimates from the U.S. Census Bureau indicate that the median level of net worth is $\$ 7,424$ for Latinos. In contrast, the median net worth for white, non-Latinos is $\$ 110,729$. The median net worth for Asians is $\$ 69,590$.

These findings from the previous literature suggest that relatively low levels of wealth among Latinos and the relatively high levels of wealth among Asians may be a source of racial differences in rates of business ownership. Indeed, recent research using statistical decomposition techniques provides evidence supporting this hypothesis. Fairlie and Woodruff (2007) examine the causes of low rates of business formation among Mexican-Americans. Relatively low levels of assets explain roughly one quarter of the business entry rate gap for Mexican-Americans. Lofstrom and Wang (2009) using SIPP data also find that low levels of wealth for Mexican-Americans and other Latinos work to lower self-employment entry rates. Apparently, low levels of personal wealth limit opportunities for Mexican-Americans and other Latinos to start businesses.

Recent research, however, indicates that immigrant-owned businesses overall start with higher levels of startup capital than non-immigrant owned businesses (Fairlie 2012). Nearly 20 percent of immigrant owned firms started with $\$ 50,000$ or more in financial capital compared with 15.9 percent of non-immigrant owned firms. Hispanic immigrant

\footnotetext{
${ }^{6}$ The largest source of startup capital for businesses is personal and family savings and the majority of small business loans require personal commitments by owners (U.S. Census Bureau 2006; Avery, Bostic and Samolyk 1998).
} 
firms have lower levels of startup capital than the immigrant total and Asian immigrant firms have higher levels of startup capital. The most common source of startup capital for immigrant-owned businesses is personal or family savings with roughly two-thirds of businesses reporting this source of startup capital. Other common sources of startup capital used by immigrant firms are credit cards, bank loans, personal or family assets, and home equity loans. The sources of startup capital used by immigrant firms do not differ substantially from those used by non-immigrant firms.

\section{Home Country Business Experience}

The relationship between home country self-employment experiences and host country self-employment is not well understood. Previous research indicates that homecountry self-employment rates are either positively associated with self-employment rates in the United States (Yuengert 1995) or that the two are not significantly associated (Fairlie and Meyer 1996). Immigrants from Mexico also provide a clear outlier for a positive relationship (Fairlie and Woodruff 2007). Roughly one fourth of Mexico's workforce is a self-employed business owner. In contrast, the Mexican immigrant rate of self-employment is only 6 percent in the United States -- a rate of self-employment that is substantially lower than the national average of 11 percent. It is possible that although previous home country self-employment experience is useful it is overwhelmed by other constraints to starting businesses in the United States such as limited access to capital, low educational levels, and limited English language ability (Lofstrom and Wang 2009; Fairlie and Woodruff 2007, 2010). 
The absence of a good understanding of the role of home country business experience is at least partly due to a lack of suitable individual level data that includes pre-migration self-employment information. As Akee, Jaeger and Tatsiramos (2008) shows, the availability of relatively recent data from the New Immigrant Survey (NIS) provides an opportunity to overcome this hurdle. Using the NIS, they test whether immigrant who reported being self-employed in their home country are also more likely to be self-employed in the U.S. and whether the pre-migration entrepreneurial experience affects earnings in the U.S. They find that home country self-employment increases the probability of self-employment in the U.S. by about 7 percentage points and are consistent with a positive effect on self-employment earnings.

\section{Ethnic Enclaves}

A potential contributor to the higher rates of business ownership among immigrants overall, and especially immigrants from Asia, is the residential concentration of co-nationals or co-ethnics in certain urban areas, so called enclaves. The earlier research on this comes from the sociology literature in the context of ethnic resources as a determinant in an individual's choice of whether or not to choose self-employment (see for example Light, 1972, Light and Bonacich, 1988 and Aldrich and Waldinger, 1990). Examples of ethnic resources are skills or knowledge to provide services or goods to other co-ethnics or co-nationals, availability of low wage labor, social support networks that assist an individual in obtaining necessary start-up capital or in transferring managerial skills. Aldrich and Waldinger (1990) describe “opportunity structures” as market conditions that may favor goods or services oriented towards co-ethnics or co- 
nationals. Locating in an ethnic enclave may provide a market for special products and services and access to co-ethnic labor. ${ }^{7}$ With respect to the latter, entrepreneurs may have an opportunity to take advantage of co-nationals limited labor market choices, especially recently arrived immigrants, due to language and cultural barriers. It then follows, it is argued, that immigrants who are living in areas with relatively high proportions of conationals may have a comparative advantage in providing certain goods or services, food or restaurant services for example, to their co-nationals compared to natives or other immigrants. A consequence, according to this theory, is higher self-employment rates among immigrants living in enclaves.

Existing research examining the impact of ethnic enclaves on the success (and thus economic contribution) of immigrant entrepreneurs frequently finds that locating in an ethnic enclave may indeed enhance opportunities and spur self-employment. For example, Wilson and Portes (1980) find evidence in support of the enclave hypothesis for a sample of Cuban immigrants living in Miami. Using a measure of enclave at the Standard Metropolitan Statistical Area (SMSA) level, Borjas (1986) finds that selfemployment among Mexicans, Cubans, and "other Hispanics" is increasing in the percentage of Hispanics in an SMSA. The effect is larger among the immigrant population than among the population born in the U.S. Using 2000 Census data, Fairlie and Woodruff (2007) find that Mexican immigrant self-employment rates are higher in ethnic enclaves. Other evidence in support of the positive relationship between enclaves and business ownership rates extending beyond Hispanics can be found in Yoon (1995), Sanders and Nee (1996) and Lofstrom (2002). However, the evidence is more mixed on

\footnotetext{
${ }^{7}$ Other early studies making this argument include Kinzer and Sagarin (1950) and Glazer and Moynihan (1970).
} 
whether black self-employment is higher in areas with larger concentrations of blacks (see Boyd 1990 and Dawkins 2007 for example).

Ethnic enclaves may explain why some ethnic groups have high rates of business ownership, but enclaves can also dampen opportunities for entrepreneurs by creating intense competition among co-ethnics (Aldrich and Waldinger 1990 and Razin and Langlois 1996). Other research has proposed that disadvantaged minorities may turn to self-employment as a survival strategy, possibly due to employment discrimination (Light and Roach, 1986). If so, higher rates of business ownership are not so much the results or signs of success but represent a reflection of blocked opportunities in wage/salary employment. This is an important issue since in this context the contributions of immigrant entrepreneurs are likely to be lower and is at times analyzed from a so-called push versus pull perspective where a "push" factor is one where individuals decide to start businesses when no other attractive alternatives are available and higher economic returns and the non-monetary benefits of business ownership are considered “pull” factors. However, determining empirically under what circumstances some factors motivate while others discourage self-employment through the push vs. pull lens can arguably be compared to deciding which blade of the scissors cut the paper.

\section{Legal Status and Undocumented Immigrants}

Another potential barrier to business ownership among immigrants is legal status. Legal status may affect the decision to start a business for several reasons. First, legal status is a prerequisite for access to many institutions which are important to entrepreneurs. Legal residents have access to the court system, should disputes arise with 
employees or customers. Legal status may also be required for participation in government contracts. Legal migrants are more likely to own property which might be used as collateral, and hence have access to credit. These factors suggest that legal status should result in higher levels of business ownership. On the other hand, Kossoudji and Cobb-Clark (2002) find that Latino wage and salary workers gaining legal status through IRCA experienced wage increases, which increase the opportunity costs of starting a business. ${ }^{8}$ Hence, the association between legal status and business ownership is theoretically ambiguous.

A large share of the Mexican-born population residing in the United States is estimated to be undocumented (Costanzo et al, 2001; Passel, Capps and Fix 2004). Fairlie and Woodruff (2010) use a sample of undocumented immigrants from the Legalized Population Survey (LPS) and the Immigration Reform and Control Act of 1986 (IRCA) as a natural experiment to assess the impact of legal status on Mexican-American business ownership. They find that legal status has an important impact on business ownership rates among Mexican immigrants. Given estimates that half or more of the Mexican-born population in the United States in 2000 was in the country illegally, legal status accounts for at least 0.7 percentage points in the business ownership rate of male and female Mexican immigrants. The benefits of legal status for business ownership thus appear to outweigh the increased opportunity costs associated with higher wages.

Lastly, more recently there is evidence that increased enforcement of employer sanctions against the hiring of unauthorized immigrants in wage/salary employment may lead to higher self-employment rates (Bohn and Lofstrom, 2013). They report that in this context

\footnotetext{
${ }^{8}$ More recent research, however, does not find evidence of large positive effects of legalization on labor market outcomes (Lofstrom, Hill and Hayes, 2013).
} 
increases in reported self-employment is not particularly welcome news as it is most likely associated with growth in lower paid informal employment.

\section{Immigrant Business Performance}

The contributions of immigrant entrepreneurs rest at least partly on their performance as business owners. As shown in our overview section of immigrant entrepreneur contributions, a number of measures can be used to shed light on this issue. Of these, earnings or income has played the most prominent role in the literature.

The economic returns to self-employment in general have been rather extensively examined. Studies from the 1980s find that potential wages and wage growth of entrepreneurs are higher or not significantly different from the wages and growth of paid employees (for example, Brock and Evans, 1986; Rees and Shah, 1986 and Evans and Leighton, 1989). However, Hamilton (2000) shows that these results are influenced by a handful of high-income entrepreneurial "superstars" and that most entrepreneurs have both lower initial earnings and lower earnings growth than they would receive in wage/salary employment. The observed and previously reported higher average earnings may thus not characterize the self-employment returns of most business owners. To what extent this applies to immigrant entrepreneurs is not entirely clear. This, as in the general literature, is primarily due to the difficulty in finding valid instruments that credible generates exogenous variation in employment choices, the challenges in comparing wage/salary and self-employment earnings and the limited sources of suitable individual

level panel data that include key information such as pre-self-employment experience and length of time in business. Nonetheless, a number of papers have examined the relative performance of immigrant business owners, compared both to their wage/salary 
counterparts and the performance of other entrepreneurs. The latter research represents the relatively less empirically challenging strand of literature.

In Section 2 we report that average earnings of immigrant-owned businesses are lower than for natives. This comparison, however, hides important heterogeneity across immigrants. One issue is that immigrant business earnings tend to rise with time in the country, possibly reflecting that business ownership is stepping stone in upward economic mobility representing a tool in immigrants' economic assimilation process (Cummings 1980). Although there are a number of studies analyzing how immigrant business ownership rates changes with time spent in the new country (e.g. Borjas 1986; Clark and Drinkwater 2010; Lofstrom 2002, Schuetze 2005 and Andersson and Wadensjö 2004), not many have examined assimilation earnings patterns among immigrant selfemployed business owners.

Lofstrom (2002) analyzes both self-employment probabilities and earnings and find that both increases with time spent in the U.S. More specifically, the results based on 1980 and 1990 US Census data suggests that self-employed immigrants are relatively successful and may even reach earnings parity with observationally similar US born entrepreneurs after about 25 years in the country. This is in contrast to wage/salary immigrants for whom he does not find evidence of earnings convergence relative to their native born wage/salaried counterparts. In an analysis that also includes immigrants in Canada and Australia, Antecol and Schuetze, (2007) find that in all three countries selfemployment increases with time in the country but that in terms of earnings outcomes relative to natives, self-employed immigrants in the U.S out-performed immigrants to those two countries. This is an interesting and policy relevant finding given that unlike 
immigrants to Canada and Australia, U.S. immigrants are not extensively selected and admitted based on skills.

A relevant strand of literature is the one that examines earnings growth, including those comparative studies of minority groups that are predominantly immigrants. Those studies, which mostly focus on disadvantaged groups, provide some evidence of relatively successful immigrant entrepreneurs. For example, Fairlie (2004), utilizing the National Longitudinal Survey of Youth (NLSY), finds evidence of faster earnings growth among self-employed Latino men than among male Latino wage /salary workers. Focusing on low-skilled workers and relying on data form the Survey of Income and Program Participation (SIPP), Lofstrom (2011) builds on this work and finds that the returns to low-skilled self-employment among immigrants is higher than it is among natives. However, in spite of relatively rapid earnings growth, he also finds that wage/salary employment appears to be a more financially rewarding option for most lowskilled immigrants. He concludes "The lack of strong evidence of relative success among low-skilled immigrant entrepreneurs suggests that previous finding of greater labor market assimilation among self-employed immigrants is driven by the relative success of the comparatively higher skilled immigrant entrepreneurs” (p.43).

\section{Differences across Immigrant Groups}

A few previous studies have also examined whether business earnings and performance differ by source countries. These studies generally find high levels of business earnings among Asian immigrant groups and lower levels among Latino immigrant groups. 
From this strand of research, Asian immigrant owned businesses are generally found to perform better than native owned businesses. Fairlie and Robb $(2008,2011)$ using data the Characteristics of Business Owners (CBO) find that Asian-owned businesses, which are 80 percent immigrant owned, have higher sales and profits, and are more likely to survive and hire employees than are non-Hispanic white owned businesses. Using Blinder-Oaxaca and non-linear decompositions they identify the causes of these differences. They find that high levels of startup capital explain roughly 50-100 percent and high levels of education explain 8-26 percent of why Asian-owned businesses perform better on average.

Fairlie, Zissimopoulos and Krashinsky (2010) compare business income among Asian immigrants in the United States and Canada. They find that Asian immigrant owned businesses have slightly higher average earnings than the national average in the United States, but slightly lower average earnings than the national average in Canada. Partly explaining the U.S. pattern, Asian immigrant business owners are found to have substantially higher education levels than the national average.

There are some notable differences across Asian immigrant groups in the United States, however. The highest levels of business earnings are found for immigrants from India, Pakistan, and the Philippines, and the lowest levels of earnings are found for immigrants from Vietnam and Bangladesh. In related work, Fairlie, et al. (2010) find that Indian immigrants have the highest level of business earnings across all immigrant groups and not just Asian groups. Indian business owners have average earnings of $\$ 84,080$, which significantly higher than the national average of $\$ 52,086$ in 2000 . This differential is especially surprising given that India's low per capita income -- only 
\$2,644 adjusted for purchasing power parity. But, Indian business owners in the United States are found to be highly educated with nearly 70 percent having at least a 4-year college degree. These high levels of education among Indian immigrants in the United States are responsible for nearly half of the higher level of entrepreneurial earnings while industry differences explain an additional 10 percent. In Canada, Indian entrepreneurs have average earnings slightly below the national average but they are more likely to hire employees, as are their counterparts in the United States and United Kingdom. The Indian educational advantage is smaller in Canada and the United Kingdom contributing less to their entrepreneurial success.

As noted in Table 4, immigrant business owners from Mexico comprise roughly one quarter of all immigrant business owners in the United States. Not surprisingly then a few recent studies have focused on this group. In recent research, Lofstrom and Wang (2009) find, using the 1996 and 2001 Survey of Income and Program Participation (SIPP), that relatively low levels of education and wealth contribute to lower businesscreation rates among Mexican-Americans. Using the 2000 Census, Fairlie and Woodruff (2010) find that differences in age, education and marital status explain part of the lower business ownership rate among Mexican-Americans, compared with the entire U.S. labor force. Focusing on earnings, Fairlie (2004) finds evidence of faster earnings growth among self-employed Latino men than among male Latino wage and salary workers from the National Longitudinal Survey of Youth, and Zuiker (1998) finds evidence that selfemployment helps more than half of Latinos in the Southwest escape poverty.

Examining the causes of both low levels of business formation and business income among Mexican-Americans, Fairlie and Woodruff (2010) find that low levels of 
education and wealth explain the entire gap between Mexican immigrants and non-Latino whites in business formation rates; together with language ability, these factors explain nearly the entire gap in business income. Legal status represents an additional barrier for Mexican immigrants, reducing business ownership rates by 0.7 percentage points. Human and financial capital deficiencies limit business ownership and business success among second and third-generation Mexican-Americans to a lesser extent.

Some of this work has focused more specifically on Latinas. Lofstrom and Bates (2009) observe that Latina entrepreneurs have lower average earnings than both white female entrepreneurs and Latina employees. However, once differences in mean observable characteristics are taken into account Latina entrepreneurs often do well and are even estimated to earn more than observationally similar non-minority white female Entrepreneurs (but still slightly less than observationally similar wage/salary employed Latinas).

\section{Crowd out, Spillovers and Diversity}

A more complete picture of the contributions of immigrant entrepreneurs requires a look beyond the performance and impacts of the business owners. That is, the contributions need to be viewed in the light of how it may enhance economic growth and innovation but also through the lens of crowd out. For example, if there are large negative displacement effects on natives from immigrant business ownership, positive contributions are to some extent diminished. We next review the relatively young literature that aims to shed light on immigrant entrepreneurship spillover effects. 
The first study in this strand of the economics literature used 1980 and 1990 Census microdata and a number of estimation techniques and measures of self-employment and immigration to examine the impact on native born entrepreneurs (Fairlie and Meyer 2003). Their findings provide some evidence that immigration may negatively affect native self-employment probabilities. The first-difference estimates indicate that somewhere between 0.37 to 0.85 self-employed native men and 0.09 to 0.19 selfemployed native women are displaced by each self-employed immigrant. However, they also report that this is not corroborated by the predictions of their general equilibrium model or using the 1980 and 1990 cross-sections. In light of some evidence of a negative impact on native self-employment rates, surprisingly the analysis of the effects of immigration on native self-employment earnings suggests that immigration increases native self-employment earnings. In light of the less than clear picture of the role of immigration on native business owners, they postulate that the results "may be due to immigrants primarily displacing marginal or low-income self-employed natives, but our analyses do not provide clear evidence supporting this hypothesis” (p. 647).

More recent work focusing on innovations point rather unambiguously toward positive spillover effects of immigrant entrepreneurs. In this context the research concentrate on innovation as measured by patents, licensing and publications and contributions are not limited to immigrant business owners. This is motivated by the observation that immigrants are greatly over-represented among US-based Nobel Prize winners (Peri 2007), high-impact companies (Hart and Acs 2011), patent applications (Wadhwa et al 2007) and members of the National Academy of Sciences and the National Academy of Engineering (Hunt and Gauthier-Loiselle 2010). More directly 
related to business ownership, immigrants are also over-represented among founders of high-tech companies (Saxenian 2002 and Wadhwa et al 2007), biotech firms (Monti, Smith-Doerr and MacQuaid 2007), biotech companies undergoing initial public offerings (Stephan and Levin 2001) and public venture-backed US companies (Anderson and Platzer 2006). With respect to immigrant high-tech contributions, Hart and Acs (2011) present evidence that suggests that although immigrants play an important role in this important sector of the economy, "most previous studies have overstated the role of immigrants in high-tech entrepreneurship (p.116). The challenging empirical question of whether these types of observed relationships are causal is what some very interesting recent papers have tackled. Using different identification strategies, two papers in particular stand out here; Hunt and Gauthier-Loiselle (2010) and Kerr and Lincoln (2010).

Using a state level panel for the period 1940-2000 and the 1940 distribution of skilled immigrants as an instrument for later location choices, Hunt and Gauthier-Loiselle (2010) find that skilled immigrants strongly contribute to innovation in the U.S. For example, the IV estimates suggest that the increase in the share of the population of immigrants with at least a college degree increased patenting per capita by about 21 percent. Moreover, they point out that their analysis does not suggest that immigrants are innately more able than natives but that the higher rate of patenting among college graduate immigrants is entirely explained by the greater share of immigrants with science and engineering education compared to natives.

Kerr and Lincoln (2010) take a different approach to assess the impact of high-skilled immigration on technology formation as measured by science and engineering 
employment and patenting. In addition to variation across cities and firms, they take advantage of the substantial changes in the cap on new visas issued for the largest and arguably most important temporary visa programs currently in place in the U.S.; the H1B program. ${ }^{9}$ They focus on the largest source country group of $\mathrm{H}-1 \mathrm{~B}$ holders, those from India and China as well as the most relevant occupations, science and engineering (SE). They find that changes in the $\mathrm{H}-1 \mathrm{~B}$ population account for a significant share of the growth in U.S. immigrant science and engineering employment. Importantly, they rule out crowding out effects on labor market outcomes (employment levels, unemployment rates and mean wages) of native scientists and engineers and the results suggest potentially small crowding-in effects.

Another potential measure of the contribution of immigrant-owned businesses is exports. The ability of firms to export goods and services outside of the U.S. market represents a measure of current success and the potential for future, long-term success of firms. To the extent that immigrant-owned businesses can export (to their home countries) it expands total revenues coming into the United States. For the first time, the 2007 SBO included information on both owner's immigrant status and exports. Specially commissioned tabulations of export levels for immigrant and non-immigrant businesses from the 2007 SBO are reported in Table 8. Similar to sales, employment and payroll these data are not available for immigrant businesses in published reports by the Census

\footnotetext{
${ }^{9}$ The H-1B program allows U.S. businesses to temporarily employ high-skilled foreign workers in key specialty occupations generally requiring at least a bachelor's degree. The H-1B visa is valid for three years and is renewable once for an additional three years. New visas are subject to an annual cap - which is one source of the controversy of the program - currently set at 65,000 visas (but which has been as high as 195,000). Exemptions from the cap include those workers hired by universities and non-profit research institutes and 20,000 individuals who hold a master's degree or higher from a U.S. university
} 
Bureau. The reported percentages represent the share of total sales of goods and services represented by exports outside of the United States.

Table 8

Immigrant Share of Businesses by Export Level

Special Tabulations from Survey of Business Owners 2007

\begin{tabular}{lrrr} 
& \multicolumn{2}{c}{$\begin{array}{c}\text { Immigrant Firms } \\
\text { Percent of Percent of } \\
\text { Immigrant Export Level }\end{array}$} \\
$\begin{array}{lrrr}\text { Notive-Born Firms } \\
\text { Export Level }\end{array}$ & $\begin{array}{l}\text { Total } \\
\text { Total }\end{array}$ & Percent of Total \\
\hline None & $92.9 \%$ & $12.7 \%$ & $95.2 \%$ \\
Less than 1\% & $1.4 \%$ & $11.1 \%$ & $1.7 \%$ \\
$1 \%$ to $4 \%$ & $1.0 \%$ & $14.7 \%$ & $0.9 \%$ \\
$5 \%$ to $9 \%$ & $0.6 \%$ & $17.1 \%$ & $0.5 \%$ \\
$10 \%$ to $19 \%$ & $0.8 \%$ & $20.2 \%$ & $0.5 \%$ \\
$20 \%$ to $49 \%$ & $1.0 \%$ & $24.8 \%$ & $0.5 \%$ \\
$50 \%$ to $99 \%$ & $1.2 \%$ & $35.1 \%$ & $0.4 \%$ \\
$100 \%$ & $1.0 \%$ & $50.5 \%$ & $0.3 \%$ \\
Total reporting & $100.0 \%$ & $13.0 \%$ & $100.0 \%$ \\
\hline
\end{tabular}

Note: (1) The sample includes businesses that are classified by the IRS as sole proprietorships, partnerships, 1120 corporations, or employers, and that have sales of $\$ 1000$ or more. (2) Excludes publicly held and other firms not classifiable by owner status.

Immigrant-owned businesses are more likely to export than are non-immigrant owned businesses. Among immigrant firms, 7.1 percent export compared with 4.4 percent of non-immigrant firms and 4.8 percent of all firms. Immigrant firms are also more likely to have very high levels of exports with 3.2 percent of immigrant firms having exports that represent 20 percent or more of their total sales of goods and services. In comparison, less than 1 percent of non-immigrant firms and 1.2 percent of all firms have exports that represent 20 percent or more of their total sales.

Immigrant-owned businesses constitute a very large share of businesses with high levels of exports. Immigrant-owned businesses constitute one-quarter of all businesses with exports of 20 to 49 percent of total sales, 35.1 percent of all businesses with exports 
of 50 to 99 percent, and 50.5 percent of all businesses with exports representing 100 percent of total sales.

Immigrant-owned firms may have higher levels of exports than non-immigrant owned firms because of business networks with their home countries, similar languages and cultural ties. Regardless of the underlying cause, higher levels of exports among immigrant owned firms may help these firms better succeed in the long run. Exports are also important for alleviating the large U.S. trade imbalance with the rest of the world and have been emphasized as a way to create jobs (U.S. Whitehouse 2010). Evidence of the positive effects of immigrant entrepreneurs on exports is found in Rauch and Casella (1998) and Rauch and Trindade (2002) who show that co-ethnic networks promote bilateral trade by providing market information as well as by supplying matching and referral services.

\section{Conclusions and Areas for Future Research}

Immigrants are widely perceived as being highly entrepreneurial and important for economic growth and innovation. This is reflected in immigration policies and many developed countries have created special visas and entry requirements in an attempt to attract immigrant entrepreneurs. Not surprisingly, a significant body of research on immigrant entrepreneurship has developed over the years. In this chapter we provide an overview of the economics literature through the lens of immigrant business owners' net contributions to the economy.

Immigrant entrepreneurs are not a homogenous group and hence their experiences and contributions vary widely across ethnic and source country groups. Although there is 
some evidence that self-employment is associated with some upward economic mobility for disadvantaged workers, groups that are characterized by relatively low skill levels have not experienced the same degree of success as those with higher levels of human capital.

Overall, much of the existing research points towards positive net contributions by immigrant entrepreneurs. The emerging literature on these contributions as measured by innovations represents the most convincing evidence so far. However, some fundamental issues have yet not been credibly addressed. First, there is little evidence in the literature on how much immigrant-owned businesses contribute to job growth. Although data exists on employment among immigrant-owned businesses no data are available showing the dynamics of employment among these firms. More research is clearly needed on the contribution of immigrant firms to U.S. exports. Immigrant business owners are more likely to export, but we know little about how much they export in total dollars and how many jobs are created by these expanded markets for selling goods and services. Another area of research needed is the contribution of immigrant businesses to diversity. Although the contribution of immigrant firms to diverse restaurants, merchandise and services is apparent in any visit to a major U.S. city, we know less about the contribution to diversity in manufacturing and design of innovative products. In all of these cases, finding data will pose substantial challenges. 


\section{References}

Aldrich, Howard E., and Roger Waldinger. 1990. "Ethnicity and Entrepreneurship." Annual Review of Sociology, 16(1): 111-135.

Anderson, Stuart, and Michaela Platzer. 2006. “American Made: The Impact of Immigrant Entrepreneurs and Professionals on U.S. Competitiveness”, National Venture Capital Association, Arlington, VA.

Andersson, Pernilla and Eskil Wadensjö 2005. "Self-employed Immigrants in Denmark and Sweden - a Way to Economic Self-Reliance?” IZA Discussion Paper No. 1130.

Antecol, Heather and Herbert J. Schuetze, 2007 "Immigration, Entrepreneurship and the Venture Start-Up Process", International Handbook Series on Entrepreneurship eds. Simon C. Parker, Zoltan J. Acs, and David R. Audretsch: Kluwer Academic Publishers, Volume 2.

Black, Jane, David de Meza, and David Jeffreys. 1996. "House Prices, The Supply of Collateral and the Enterprise Economy." The Economic Journal. 106 (434):60-75.

Blanchflower, David G., and Andrew J. Oswald. 1998. "What Makes an Entrepreneur?" Journal of Labor Economics, 16 (1), pp. 26-60.

Blinder, Alan S. 1973. "Wage Discrimination: Reduced Form and Structural Variables." Journal of Human Resources 8: 436-455.

Bohn, Sarah and Magnus Lofstrom. 2013 “Employment Effects of State Legislation”, in David Card and Steven Raphael (eds.) Immigration, Poverty, and Socioeconomic Inequality, Russell Sage, pp. 282-314.

Borjas, George. 1986. “The Self-Employment Experience of Immigrants” Journal of Human Resources, 21, Fall: 487-506.

Borjas, George. 1994 “The Economics of Immigration,” Journal of Economic Literature, 32, 1667-717.

Bradford, William D. 2003. "The Wealth Dynamics of Entrepreneurship for Black and White Families in the U.S.," Review of Income and Wealth, 49(1): 89-116.

Bucks, Brian K., Arthur B. Kennickell, and Kevin B.Moore. 2006. "Recent Changes in U.S. Family Finances: Evidence from the 2001 and 2004 Survey of Consumer Finances," Federal Reserve Bulletin, Washington, D.C.: Board of Governors of the Federal Reserve System. 
Clark, Kenneth and Stephen Drinkwater. 2000. "Pushed out or pulled in? Selfemployment among ethnic minorities in England and Wales." Labour Economics. 7, pp.603-628.

Clark, Kenneth and Stephen Drinkwater. 2010. "'Patterns of Ethnic Self-Employment in Time and Space: Evidence from British Census Microdata” Small Business Economics, 2010, 34 (3), 323-338

Cobb-Clark, Deborah A., and Vincent Hildebrand. 2004. "The Wealth of Mexican Americans," IZA Discussion paper No. 1150.

Dunn, Thomas A. and Douglas J. Holtz-Eakin. 2000. "Financial Capital, Human Capital, and the Transition to Self-Employment: Evidence from Intergenerational Links," Journal of Labor Economics 18 (2): 282-305.

Evans, David and Boyan Jovanovic. 1989. "An Estimated Model of Entrepreneurial Choice Under Liquidity Constraints." Journal of Political Economy 97(4):808-27.

Evans, David, and Linda Leighton. 1989. "Some Empirical Aspects of Entrepreneurship," American Economic Review, 79, pp. 519-535.

Fairlie, Robert W. 1999. "The Absence of the African-American Owned Business: An Analysis of the Dynamics of Self-Employment." Journal of Labor Economics, 17(1): 80108.

Fairlie, Robert W. 2004. "Does Business Ownership Provide a Source of Upward Mobility for Blacks and Hispanics?," Entrepreneurship and Public Policy, ed., Doug Holtz-Eakin, Cambridge: MIT Press.

Fairlie, Robert W. 2005. "An Extension of the Blinder-Oaxaca Decomposition Technique to Logit and Probit Models," Journal of Economic and Social Measurement, 30(4): 305316.

Fairlie, Robert W. 2006. "Entrepreneurship among Disadvantaged Groups: An Analysis of the Dynamics of Self-Employment by Gender, Race and Education," Handbook of Entrepreneurship, Volume 2, eds. Simon C. Parker, Zoltan J. Acs, and David R. Audretsch, Kluwer Academic Publishers, 437-478.

Fairlie, Robert W. 2008. Estimating the Contribution of Immigrant Business Owners to the U.S. Economy, U.S. Small Business Administration, Office of Advocacy, Washington, D.C.

Fairlie, Robert W. and Harry A. Krashinsky, 2005. "Liquidity Constraints, Household Wealth, and Entrepreneurship Revisited," Review of Income and Wealth, 58(2): 279-306.

Fairlie, Robert W. and Bruce D. Meyer. 2003 “The Effect of Immigration on Native 
Self-Employment” Journal of Labor Economics, vol. 21, no. 3, pp. 619-50.

Fairlie, Robert W. and Alicia M. Robb (2008) Race and entrepreneurial success: Black-, Asian-, and White-owned businesses in the United States. Cambridge, MA: MIT Press.

Fairlie, Robert W. and Alicia M. Robb. 2009. "Determinants of Business Success: An Examination of Asian-Owned Businesses in the United States," Journal of Population Economics, 22(4): 827-858.

Fairlie Robert W., Julie Zissimopoulos, and Harry A. Krashinsky. 2010. The international Asian business success story: A comparison of Chinese, Indian, and other Asian businesses in the United States, Canada, and United Kingdom. International differences in entrepreneurship, in Josh Lerner and Antoinette Shoar, eds. University of Chicago Press and National Bureau of Economic Research, 179-208.

Fairlie Robert W., Julie Zissimopoulos, Harry A. Krashinsky, and Krishna Kumar. 2012. "Indian Entrepreneurs in the United States, Canada and United Kingdom," Research in Labor Economics (forthcoming).

Fairlie Robert W., and Christopher Woodruff. 2010. "Mexican-American Entrepreneurship," The Berkeley Electronic Journal of Economic Analysis \& Policy, (Contributions), 10(1): 1-42, Article 10.

Glazer, Nathan and Daniel P. Moynihan. 1970. Beyond the Melting Pot: the Negroes, Puerto Ricans, Jews, Italians, and Irish of New York City, 2nd Edition. Cambridge: MIT Press.

Haltiwanger, John, Ron S Jarmin, and Javier Miranda. 2011. "Who Creates Jobs? Small vs. Large vs. Young," University of Maryland Working Paper.

Hart, David M. and Zoltan J. Acs 2011 "High-Tech Immigrant Entrepreneurship in the United States” Economic Development Quarterly 25:2 p.116-129.

Headd, B., and R. Saade. 2008. Do business definition decisions distort small business results? Washington, D.C. : U.S. Small Business Administration, Office of Advocacy working paper.

Holtz-Eakin, Douglas, David Joulfaian, and Harvey Rosen. 1994a. "Entrepreneurial Decisions and Liquidity Constraints." RAND Journal of Economics 23: 334-347.

Hunt, Jennifer. 2011 "Which Immigrants Are Most Innovative and Entrepreneurial? Distinctions by Entry Visa” Journal of Labor Economics, 29:3, pp. 417-457

Hunt, Jennifer, and Marjolaine Gauthier-Loiselle. 2010. "How Much Does Immigration boost innovation?” American Economic Journal: Macroeconomics, 2(2): 31-56. 
Kassoudji, Sherrie. 1988. "English Language Abilities and the Labor Market Opportunities of Hispanic and East Asian Men,” Journal of Labor Economics, 6 (2).

Kerr, William R., and William F. Lincoln. 2010. "The Supply Side of Innovation: H-1B Visa Reforms and U.S. Ethnic Invention”, Journal of Labor Economics, 28(3): 473-508.

Kerr, Sari Pekkala and William R. Kerr. 2011. “Economic Impacts of Immigration: A Survey” NBER Working Paper No. 16736.

Kinzer, Robert H., and Edward Sagarin. 1950. The Negro in American Business: the Conflict between Separatism and Integration, New York: Greenberg.

Light, Ivan. 1972. Ethnic Enterprise in America. Berkeley: University of California Press.

Lindh T., and H. Ohlsson. 1996. 'Self-employment and windfall gains: evidence from the Swedish lottery’, Economic Journal, 106: (439), November, pp.1515-1526.

Lofstrom, Magnus. 2002. "Labor market assimilation and the self-employment decision of immigrant entrepreneurs", Journal of Population Economics, 15(1), January, 83-114.

Lofstrom, Magnus, and Chunbei Wang. 2009 "Mexican-American Self-Employment: A Dynamic Analysis of Business Ownership” Research in Labor Economics, Vol. 29, pp.197-227.

Lofstrom, Magnus and Timothy Bates. 2009 “Latina Entrepreneurs”, Small Business Economics, 33:4, pp. 427-439.

Lofstrom, Magnus, Tim Bates and Simon Parker. Forthcoming, "Why Are Some People More Likely to Become Small-Businesses Owners than Others: Entrepreneurship Entry and Industry-Specific Barriers”, Journal of Business Venturing

Lofstrom, Magnus. 2011 “Low-Skilled Immigrant Entrepreneurship”, Review of Economics of the Household, 9:1, pp.25-44.

Lofstrom, Magnus, Laura Hill and Joseph Hayes. 2013 "Wage and Mobility Effects of Legalization: Evidence from the New Immigrant Survey”, Journal of Regional Science, 2013, 53:1, pp.171-197.

Monti, Daniel. J., Laurel Smith-Doerr and James MacQuaid. 2007. “Immigrant Entrepreneurs in the Massachusetts Biotechnology Industry”, Boston, MA: Immigrant Learning Center.

Oaxaca, Ronald. 1973. "Male-Female Wage Differentials in Urban Labor Markets," International Economic Review, 14 (October), 693-709. 
Oaxaca, Ronald, and Michael Ransom. 1994. "On Discrimination and the Decomposition of Wage Differentials," Journal of Econometrics, 61, 5-21.

OECD (2005). SME and Entrepreneurship Outlook - 2005 Edition, Organisation for Economic Co-operation and Development Press.

Partnership for a New American Economy and the Partnership for New York City. 2012. Not Coming to America: Why the US is Falling Behind in the Global Race for Talent.

Peri, Giovanni. 2007. "Higher Education, Innovation and Growth.” in Education and Training in Europe, ed. Giorgio Brunello, Pietro Garibaldi, and Etienne Wasmer, 56-70. Oxford: Oxford University Press.

Rauch, James E., and Casella, Alessandra. 1998 “Overcoming Informational Barriers to International Resource Allocation: Prices and Group Ties” National Bureau of Economic Research working paper no. 6628.

Rauch, James E. and Vitor Trindade. 2002. “Ethnic Chinese Networks in International Trade”, Review of Economics and Statistics 84:1, pp. 116-130.

Razin, Eran and Andre Langlois. 1996. "Metropolitan Characteristics and Entrepreneurship among Immigrants and Ethnic Groups in Canada, International Migration Review, 30(3): 703-727.

Reynolds, Paul. 2005. Entrepreneurship in the US: The Future is Now. Springer.

Sanders, Jimy M. and Victor Nee. 1996 "Immigrant Self-Employment: The Family as Social Capital and the Value of Human Capital” American Sociological Review, Vol. 61, No. 2, pp. 231-249.

Saxenian, A. 1999. Silicon Valley’s new immigrant entrepreneurs, San Francisco: Public Policy Institute of California.

Saxenian, A. 2000. Networks of immigrant entrepreneurs. In The Silicon Valley edge: A habitat for innovation and entrepreneurship. C. Lee, W. F. Miller, and H. S. Rowen, eds. Stanford: Stanford University Press.

Saxenian, A. 2002. “Silicon Valley’s New Immigrant High-Growth Entrepreneurs” Economic Development Quarterly, 16, p. 20-31.

Schuetze, H. J., and H. Antecol. 2007. Immigration, entrepreneurship and the venture start-up process. The life cycle of entrepreneurial ventures: International handbook series on entrepreneurship, vol. 3, S. Parker, ed. Springer: New York. 
Singer, Audrey. 2012. Immigrant Workers in the U.S. Labor Force, Brookings Institute and Partnership for a New American Economy Report.

Stephan, Paula E., and Sharon G. Levin. 2001. "Exceptional Contributions to US Science by the Foreign-Born and Foreign-Educated." Population Research and Policy Review, 20:(1-2), pp. 59-79.

Taylor, Mark. 2001. "Self-Employment and Windfall Gains in Britain: Evidence from Panel Data." Economica. 63, pp. 539-565.

U.S. Department of Homeland Security. 2011. 2010 yearbook of immigration statistics, Washington, D.C.: Office of Immigration Statistics, http://www.dhs.gov/xlibrary/assets/statistics/yearbook/2010/ois_yb_2010.pdf.

U.S. Department of Homeland Security 2012. EB-5 Immigrant Investor, http://www.uscis.gov.

U.S. Small Business Administration, Office of Advocacy. 2011. Research and Statistics, http://www.sba.gov/advocacy/847.

Wadhwa, V., A. Saxenian, B. Rissing, and G. Gereff. 2007. America's new immigrant entrepreneurs. Durham, NC: Duke University.

Yoon, I. (1995), 'The growth of Korean immigrant entrepreneurship in Chicago'. Ethnic and Racial Studies 18, 215-235.

Yuengert, Andrew M. 1995. "Testing Hypotheses of Immigrant Self-Employment." Journal of Human Resources 30(1):194-204.

Zissimopoulos, Julie, Lynn Karoly, and Qian Gu. 2009. " Liquidity Constraints, Household Wealth, and Self-Employment: The Case of Older Workers," RAND Working Paper. 


\section{Appendix A: Data Sources on Immigrant Entrepreneurship}

With varying degrees of limitations, there are a number of data sources for analyzing immigrant entrepreneurship in the U.S. We briefly review the most relevant ones.

The three of the nationally representative Census Bureau datasets used above are described below. These datasets are the ones with large enough sample sizes to study immigrant business owners in detail. Two of the datasets are household surveys -- the American Community Survey and the Current Population Survey -- and provide information on business ownership, startup activity and business income. The third dataset is a business-level survey -- the Survey of Business Owners -- and provides information on business sales, employment, payroll and exports. The datasets also provide detailed information on immigrant owners such as source country, skill level, state of residence, and industry of business.

The American Community Survey

The primary sample used to examine immigrant business ownership and net business income is the American Community Survey (ACS). Starting with the data collected in 2005 , the ACS is a $1 \%$ nationally representative survey with microdata for about 11.6 million observations for adults in recent years. Even after conditioning on business ownership, the sample size is very large, allowing one to explore the causes of differences in net business income. The ACS is also large enough to examine state, industrial, skill level and country-of-origin differences across immigrant business owners. 
Using the ACS data, business ownership is measured based on the class-ofworker question that refers to the respondent's main job or business activity (i.e., activity with the most hours) at the time of the interview. Business owners are individuals who report that they are 1) "self-employed in own not incorporated business, professional practice, or farm," or 2) "self-employed in own incorporated business, professional practice, or farm." This definition includes owners of all types of businessesincorporated, unincorporated, employer, and non-employer firms. Commonly defined samples include all business owners ages 18 and over who work 15 or more hours per week in their businesses. To rule out very small-scale businesses, disguised unemployment, or casual sellers of goods and services, typically only business owners with 15 or more hours worked are included. ${ }^{10}$ Fifteen hours per week is often chosen as the cutoff because it represents a reasonable amount of work effort in the business, about two days per week. Note that self-employed business ownership is defined as the individual's main job activity, thus removing the potential for counting side businesses owned by wage-and-salary workers.

\section{The Matched Current Population Survey}

Although research on entrepreneurship is growing rapidly, very few national datasets provide information on recent trends in business formation. The measure to study immigrant business startup activity can be derived from matched data from the Current Population Surveys (CPS). The measure captures the rate of business creation at the individual owner level. The underlying datasets used to create the entrepreneurship or business formation measure are the basic monthly files of the CPS. Although the CPS is

\footnotetext{
${ }^{10}$ Some unemployed individuals may report being self-employed if they sell a small quantity of goods or services while not working at their regular jobs.
} 
commonly used as cross-sectional data, longitudinal data can be created by linking the CPS files over time. The surveys, conducted monthly by the U.S. Bureau of the Census and the U.S. Bureau of Labor Statistics, are representative of the entire U.S. population and in recent years contain observations for more than 130,000 people. For example, combining the 2007 to 2010 monthly data creates a sample size of 3.8 million adult observations.

Households in the CPS are interviewed each month over a four-month period. Eight months later they are re-interviewed in each month of a second four-month period. Thus, individuals who are interviewed in January, February, March, and April of one year are interviewed again in January, February, March, and April of the following year. The rotation pattern of the CPS thus allows for matching information on individuals monthly for 75 percent of all respondents to each survey. To match these data, we use the household and individual identifiers provided by the CPS and removes false matches by comparing race, sex, and age codes from the two months. All non-unique matches are also removed from the dataset. Monthly match rates are generally between 94 and 96 percent, and false positive rates are very low.

The business formation rate is estimated by first identifying all individuals who do not own a business as their main job in the first survey month, then matching CPS files to determine whether they own a business as their main job (with 15 or more usual hours worked per week) in the following survey month. The business formation rate is thus defined as the percentage of the population of non-business owners who start a business each month. To identify whether they are business owners in each month, information on their main job, defined as the one with the most hours worked, is used. 
Thus, individuals who start side or casual businesses are not counted if they are working more hours on a wage-and-salary job.

The 2007 Survey of Business Owners

Estimates of business ownership and formation rates and of the net business income of owners are available using Census and CPS microdata, but another source of information is provided by business-level data, where the business, rather than the owner, is the focus of the analysis. The main advantage of business-level data is that they typically provide more information on business performance than individual-level data, but the main disadvantage is that they do not include information on the demographic characteristics of the owner. ${ }^{11}$ The only large nationally representative business-level data set in which the immigrant status of the owner is identifiable is the 2007 SBO. For the first time since 1992 (then called the Characteristics of Business Owners), the U.S. Census Bureau in 2007 collected information on the immigrant status of business owners in its main database collecting information on the ownership characteristics of U.S. businesses. The SBO is conducted by the U.S. Census Bureau every five years to collect statistics that describe the composition of U.S. businesses by gender, race, and ethnicity. The universe for the most recent survey is all firms operating during 2007 with receipts of $\$ 1,000$ or more that filed tax forms as individual proprietorships, partnerships, employers or any type of corporation.

The 2007 SBO includes information on whether the business owner is an immigrant which is determined by whether the owner is foreign-born vs. U.S. born. Following the convention used by the Census Bureau in reporting business statistics by

\footnotetext{
${ }^{11}$ See Headd and Saade (2008) and Fairlie and Robb (2008) for more discussion on the comparison between individual-level and business-level data on entrepreneurship.
} 
race, immigrant-owned businesses are defined as those with majority foreign-born ownership (51\% or more). Similarly, non-immigrant businesses are defined as those with majority U.S.-born ownership (51\% or more). Equally-owned firms are also reported in the tables presented below but are not included in calculating the immigrant shares.

The 2007 SBO also includes information on the sales, employment, payroll and exports of the business. Unfortunately, however, only business and employer firm counts by foreign-born status were reported in published reports by the Census Bureau. Instead, I commissioned the U.S. Census Bureau to conduct special runs using the 2007 SBO that provide information on the sales, employment, payroll and exports of immigrant-owned businesses and non-immigrant owned businesses. ${ }^{12}$

The Survey of Income and Program Participation

The U.S. Census Bureau has also generates individual level longitudinal data that can be used for analyzing various aspects of immigrant entrepreneurship. The Survey of Income and Program Participation (SIPP) contains individual demographic information as well as detailed information on labor market activities, business ownership, and business characteristics. The surveys are conducted every four months (called a "wave”) for, depending on the panel, roughly 37,000 to 47,000 U.S. households in each panel. For the most recent completed SIPP panels, the length of the panel is four years for the 1996 and 2004 panels while the 2001 panel followed individuals for only three years (The 2008 SIPP panel began in September 2008 and will run through December 2013). Importantly, given the focus on disadvantaged groups, of which many are immigrants,

\footnotetext{
${ }^{12}$ Published data from the Census Bureau also only report foreign-born owners and not businesses (which is why no sales, employment, payroll and export information is reported). We find, however, that published estimates for the SBO report show a very similar ratio of foreign-born owners to foreign-born and U.S. born owners.
} 
SIPP panels oversampled low-income households. The data are nationally representative when the provided sampling weights are used.

Each wave in the SIPP panels contain both core questions, common to each wave, and topical questions that are not updated in each wave. In addition to the key variables found in the core modules, two topical modules are particularly valuable for research on immigrant business owners: immigration (which includes information on country of origin, citizenship status, and year of arrival, collected in the second wave in each panel), and assets and liabilities (containing wealth and asset data, including business equity, collected once a year in each panel). Given the longitudinal nature of the data, it allows for dynamic analysis such as entry and exits of self-employment. 


\section{Appendix B: Utility Model Representation of Self-Employment Decision}

Typically it is assumed that the utility function is a function of expected income, or earnings if working, $y_{\mathrm{it}}^{\mathrm{s}-\mathrm{e}}$ for self-employment work and $y_{\mathrm{it}}^{\mathrm{J}}$ for participating in state $\mathrm{J}$ (for example wage/salary work, unemployment or to not participate in the labor force and where $i$ and $t$ are indices for individual $i$ at time $t$ ). Furthermore, earnings, or income, in each state will depend on a vector of observable characteristics, $\mathbf{X}_{i t}$, possible constraints faced by the individual, $\mathbf{v}_{i t}$, and unobserved characteristics $\varepsilon_{i t}$, which may represent random shocks to earnings or income opportunities and/or information known to the individual but not to the econometrician. Assuming that individuals maximize expected utility, a person will choose self-employment if the expected utility from selfemployment, denoted $E\left(u_{\mathrm{it}}^{\text {s-e }}\right)$, is greater than the expected utility in any of the other $\mathrm{J}$ states, represented here by $E\left(u_{\mathrm{it}}^{\mathrm{J}}\right)$. Expected utility in the $\mathrm{J}+1$ states can be defined as:

$$
\begin{aligned}
& E\left(u_{i t}^{J}\right)=y_{i t}^{J}+\mathbf{v}_{i t}^{J} \delta^{J}+\varepsilon_{i t}^{J}=\mathbf{X}_{i t} \beta^{J}+\mathbf{v}_{i t}^{J} \delta^{J}+\varepsilon_{i t}^{J} \\
& E\left(u_{i t}^{s-e}\right)=y_{i t}^{s-e}+\mathbf{v}_{i t}^{s-e} \delta^{s-e}+\varepsilon_{i t}^{s-e}=\mathbf{X}_{i t} \beta^{s-e}+\mathbf{v}_{i t}^{s-e} \delta^{s-e}+\varepsilon_{i t}^{s-e}
\end{aligned}
$$

where $\varepsilon^{J}$ and $\varepsilon^{s-e}$ may be assumed to be jointly normally distributed with mean zero and variances $\sigma_{J}^{2}$ and $\sigma_{s-e}^{2}$. Alternatively, the disturbances may be assumed to follow a logistics distribution. An individual chooses self-employment at time $t$ if:

$$
I_{i t}^{*}=E\left(u_{i t}^{s-e}\right)-E\left(u_{i t}^{J}\right)>0 \text {, for any state } \mathrm{J}
$$

Clearly the index function $I_{i t}^{*}$ is unobservable. However, from equations (4.1), (4.2) and (4.3) $I_{i t}^{*}$ can be defined as: 


$$
\begin{aligned}
I_{i t}^{*} & =E\left(u_{i t}^{s-e}\right)-E\left(u_{i t}^{J}\right) \\
& =\mathbf{X}_{i t} \beta^{s-e}-\mathbf{X}_{i t} \beta^{J}+\mathbf{v}_{i t}^{s-e} \delta^{s-e}-\mathbf{v}_{i t}^{J} \delta^{J}+\varepsilon_{i t}^{s-e}-\varepsilon_{i t}^{J} \\
& =\mathbf{W}_{i t} \pi+e_{i t}
\end{aligned}
$$

If we set $I=1$ if $I_{i t}^{*}>0$, if the individual is observed to have entered selfemployment at time $t$, and $I=0$ if $I_{i t}^{*} \leq 0$, if the person decides not to start up a new business, then equation (4.4) can simply be seen as a probability model of entry into selfemployment. In other words, the model can be seen as a conditional probability model where the person is observed to be not self-employed in the previous time period, i.e. at $t$ 1. Similarly, conditioning on observing the person to be in self-employment at time $t-1$, the model can represent the business ownership exit decision. The entry and exit models estimated can be represented by the following, where $I_{i t}=1$ represents an observed transition, i.e. a decision to enter or exit self-employment:

$$
\operatorname{Prob}\left[I_{i t}=1\right]=\mathbf{X}_{i t} \beta+\mathbf{v}_{\mathrm{it}} \delta+e_{\mathrm{it}}
$$

where

$\mathbf{X}_{i t} \quad=\quad$ Matrix containing observable characteristics such as age, educational attainment, marital status, number of children, immigrant status, years in residence in the U.S., geographic location.

$\mathbf{v}_{i t} \quad=\quad$ Matrix containing controls for potential business ownership constraints, or barriers, such as financial assets. 


\section{Appendix C: Decomposition Methodology}

The primary methodology used for identifying causes of immigrant/native or immigrant group differences in business ownership is the decomposition technique. This technique decompose inter-group differences (for any two groups) in mean levels of an outcome into those due to different observable characteristics or "endowments" across groups and those due to different effects of characteristics or "coefficients" of groups. The standard Blinder-Oaxaca technique is used for dependent variables that are estimated with linear regressions. For decomposing immigrant group differences in binary outcomes, such as business ownership rates, an alternative non-linear decomposition technique originally developed in Fairlie (1999) and further discussed in Fairlie (2005) is used. $^{13}$ The technique is used when logit or probit regressions are estimated to identify the determinants of business ownership or other binary business outcomes.

For a linear regression, the standard Blinder-Oaxaca decomposition of the immigrant/native gap in the average value of the dependent variable, Y, can be expressed as:

$\bar{Y}^{N}-\bar{Y}^{I}=\left\lfloor\left(\bar{X}^{N}-\bar{X}^{I}\right) \hat{\beta}^{N}\right\rfloor+\left\lfloor\bar{X}^{I}\left(\hat{\beta}^{N}-\hat{\beta}^{I}\right)\right\rfloor$,

where $\bar{X}^{j}$ is a row vector of average values of the independent variables and $\hat{\beta}^{j}$ is a vector of coefficient estimates for immigrant group $j$ (Blinder 1973; Oaxaca 1973). Following Fairlie (1999), the decomposition for a nonlinear equation, such as $Y=F(X \hat{\beta})$, can be written as:

\footnotetext{
${ }^{13}$ SAS programs are available at people.ucsc.edu/ rfairlie/decomposition, and Stata programs are available by entering "ssc install fairlie" in Stata.
} 


$$
\bar{Y}^{N}-\bar{Y}^{I}=\left[\sum_{i=1}^{N^{N}} \frac{F\left(X_{i}^{N} \hat{\beta}^{N}\right)}{N^{N}}-\sum_{i=1}^{N^{I}} \frac{F\left(X_{i}^{I} \hat{\beta}^{N}\right)}{N^{I}}\right]+\left[\sum_{i=1}^{N^{I}} \frac{F\left(X_{i}^{I} \hat{\beta}^{N}\right)}{N^{I}}-\sum_{i=1}^{N^{I}} \frac{F\left(X_{i}^{I} \hat{\beta}^{I}\right)}{N^{I}}\right],
$$

where $N^{j}$ is the sample size for immigrant group $j$. This alternative expression for the decomposition is used because $\bar{Y}$ does not necessarily equal $F(\bar{X} \hat{\beta}){ }^{14}$ In both (4.6) and (4.7), the first term in brackets represents the part of the racial gap that is due to group differences in distributions of $X$, and the second term represents the part due to differences in the group processes determining levels of $Y$. The second term also captures the portion of the racial gap due to group differences in unmeasurable or unobserved endowments. Most previous studies applying the decomposition technique do not focus on this "unexplained" portion of the gap because of the difficulty in interpreting results (see Jones 1983 and Cain 1986 for more discussion).

To calculate the decomposition, define $\bar{Y}^{j}$ as the average probability of the binary outcome of interest for immigrant group $j$ and $F$ as the cumulative distribution function from the logistic distribution. Alternatively, for a probit model F would be defined as the cumulative distribution function from the standard normal distribution.

An equally valid method of calculating the decomposition is to use the immigrant coefficient estimates, $\hat{\beta}^{I}$, as weights for the first term and the white distributions of the independent variables, $\bar{X}^{N}$, as weights for the second term. This alternative method of calculating the decomposition often provides different estimates, which is the familiar index problem with the Blinder-Oaxaca decomposition technique. A third alternative is to weight the first term of the decomposition expression using coefficient estimates from a pooled sample of the two groups or all groups, which also includes dummy variables

\footnotetext{
${ }^{14}$ Note that the Blinder-Oaxaca decomposition is a special case of (4.2).
} 
for those groups (see Oaxaca and Ransom 1994 for example). The use of this third alternative is becoming more popular.

Using the pooled coefficients from a sample of all racial groups has the advantage over using the white coefficients because it captures the determinants for all groups and are more precisely estimated (because of the larger sample and more heterogeneity of firms). They are also preferred over the minority coefficients because they are less likely to be influenced by discrimination. The goal of the decomposition is to estimate how much differences in owner or firm characteristics explain of the racial gap in business outcomes given a non-discriminatory environment.

The first term in (4.7) provides an estimate of the contribution of racial differences in the entire set of independent variables to the racial gap in the dependent variable. Estimation of the total contribution is relatively simple as one only needs to calculate two sets of predicted probabilities and take the difference between the average values of the two. Identifying the contribution of group differences in specific variables to the racial gap, however, is not as straightforward. To simplify, first assume that $\mathrm{N}_{\mathrm{B}}=\mathrm{N}_{\mathrm{W}}$ and that there exists a natural one-to-one matching of black and white observations. Using coefficient estimates from a logit regression for a pooled sample, $\hat{\beta}^{*}$ , the independent contribution of $X_{1}$ to the racial gap can then be expressed as:

$$
\frac{1}{N^{I}} \sum_{i=1}^{N^{I}} F\left(\hat{\alpha}^{*}+X_{1 i}^{N} \hat{\beta}_{1}^{*}+X_{2 i}^{N} \hat{\beta}_{2}^{*}\right)-F\left(\hat{\alpha}^{*}+X_{1 i}^{I} \hat{\beta}_{1}^{*}+X_{2 i}^{N} \hat{\beta}_{2}^{*}\right) .{ }^{\mathrm{i}}
$$

Similarly, the contribution of $X_{2}$ can be expressed as:

$$
\frac{1}{N^{I}} \sum_{i=1}^{N^{I}} F\left(\hat{\alpha}^{*}+X_{1 i}^{I} \hat{\beta}_{1}^{*}+X_{2 i}^{N} \hat{\beta}_{2}^{*}\right)-F\left(\hat{\alpha}^{*}+X_{1 i}^{I} \hat{\beta}_{1}^{*}+X_{2 i}^{I} \hat{\beta}_{2}^{*}\right) .
$$


The contribution of each variable to the gap is thus equal to the change in the average predicted probability resulting from sequentially switching the white characteristics to black characteristics one variable or set of variables at a time. ${ }^{15}$ A useful property of this technique is that the sum of the contributions from individual variables will be equal to the total contribution from all of the variables evaluated with the full sample.

In practice, the sample sizes of the two groups are rarely the same and a one-toone matching of observations from the two samples is needed to calculate (4.8) and (4.9). In this example, it is likely that the immigrant sample size is substantially smaller than the native sample size. To address this problem, first use the pooled coefficient estimates to calculate predicted probabilities, $\hat{Y}_{i}$, for each immigrant and native observation in the sample. Next, draw a random subsample of natives with a sample size equal to $\mathrm{N}_{\mathrm{I}}$ and randomly match it to the full immigrant sample. The decomposition estimates obtained from this procedure depend on the randomly chosen subsample of natives. Ideally, the results from the decomposition should approximate those from matching the entire native sample to the immigrant sample. A simple method of approximating this hypothetical decomposition is to draw a large number of random subsamples of natives, match each of these random subsamples of natives to the immigrant sample, and calculate separate decomposition estimates. The mean value of estimates from the separate decompositions is calculated and used to approximate the results for the entire native sample.

\footnotetext{
${ }^{15}$ Unlike in the linear case, the independent contributions of $X_{1}$ and $X_{2}$ depend on the value of the other variable. This implies that the choice of a variable as $X_{1}$ or $X_{2}$ (or the order of switching the distributions) is potentially important in calculating its contribution to the racial gap. A simple solution to solve this problem of path dependence (if the estimates are indeed sensitive to the ordering) is to randomize the ordering of variables at the same time the random subsample of whites is chosen (in stata use the ro option and increase the number of replications).
} 